Of these one in particular (altazimuth-observations of the moon) has originated with myself; others, from the suggestions of the Board of Visitors, or from the obvious demands of the scientific world.

This increase is felt even in our buildings and grounds ; every corner of every room is or will shortly be occupied; and the form of the ground almost forbids extension.

The printing of the steps of the reductions of observations (which originated with myself more than forty years ago) naturally increased the labour within the observatory, as well as the expenses withnut it. This printing, however, must never be abandoned. But there is another part, of which the policy still appcars to me somewbat doubtful, namely, the printing in extenso of every figure of original observations, it being remarked that the originals or extracts are always open to astronomars. brought the question of suppressing these before the Board of Visitors many years ago; but the opinions of astronomers (I cite in particular the honoured name of $\mathrm{M}$. Biot and that of $\mathrm{Mr}$. Johnson) were so strongly adverse to it, that $I$ laid aside all further thoughts of it ; and I do not even now profess to entertain a decided opinion.

The three points, however, to which I have alluded (the extent of scientific occupations, the enlargement of buildings, and the amount of printing) must before long engage the atten. tion of the Visitors.

\section{RECINT RESEARCHES AMONG THE LOWER SARCODE ORGANISMS}

THE customary annual address on the occasion of the anniversary of the Linnean Society was, on Wednesday, the 24th May, delivered by the President, Prof. Allman, F.R.S. In continuation of his last year's summary of the progress in this department of biology, he dwelt upon the important additions to our knowledge of these organisms, due to the investigations of Archer in our own country and of Hertwig and Lesser, Franz Filhard Schulze, and Greeff in Germany.

The discovery of many new monothalamic Rhizopods of fresh water and the important additions made by the British and German investigators to our knowledge of their protoplasmic bodies were brought in review before the meeting. These monothalamic forms may be divided in accordance with the nature of their pseudopodia; in some these processes being short, thick, and finger-shaped (Lobosa); in others long, slim, and filiform (Filifcra). The former were illustrated by Hyalosphenia, with its smooth, transparent shell, and by Quadrula, wiih beautifully sculptured shell; and the latter by Gromia, with its very long filiform reticulated pseudopodia; and by Microsromia socialis, vithich has the curious babit of forming colonies by the association of numerous individuals, which become united to one another by the mutual fusion of their pseudopodia, The remarkable form of reproduction discovered by Hertwig in Microgromia was also descrited. Hertwig had shown that in this Rhizopod the protoplasm divides by spontaneous fission into two segments, one of which remains in the shell, while the other forces its way out, assumes an oval shape, develops, instead of pseudopodia, two vibratile flagella, and becomes a free-swimming flagellate Zoospore, capable of ultimate development into the form of the adult. The very interesting discovery by Haeckel, that the contents of the so-called "yellow cells" of the Radiolaria become of a deep violet colour under the action of iodine, and are therefore mainly composed of starch, was also referred to among recent additions to our knowledge of the lower organisms. An account was then given of the remarkable and very significant researches of Messrs. Dallinger and Drysdale among the socalled "Monads,"-microscopic organisms which become developed in putrifying solutions of organic matter, and which, in their ordinary and apparently adult state swim about by the aid of vibratile flagella. These laborious and trustworthy investigators have shown that the flagellate monads may acquire an amceboid condition and move about by the aid of pseudopodia; that two such amoboid forms when they come in contact with one another become instantly blended together at the point of contact, that this blending becomes more and more intimate until the two individuals become completely fused together, when their mingled protoplasm assumes the form of a spherical sac filled with particles of immeasurable minuteness. These particles are germs destined for the reproduction of the individual. Their form can be demonstrated only by the highest powers of the microscope; and by following them by means of a one-fifticth of an inch object glass, Messrs. Dallinger and Drysdale were enabled to trace their gradual development into the form of the adult. They further proved the remarkable and unexpected faci: that these minute germs may be subjected to a teraperature of from $258^{\circ} \mathrm{F}$. to $300^{\circ} \mathrm{F}$. without losing their vitality and power of development, a fact of vast significance in its bearing on experiments connected with the question of spontaneous generation. Finally attention was drawn to the quite recent discovery of Hertwig and F. E. Schnize of a nucleus in the Foraminifera. By this discovery the true systematic position can now be assigned to the Foraminifera, which must accordingly be removed from the region of Cytodes or non-nucleated protoplasm masses (to which they had been hitherto relegated), and placed on a much higher stage in the great division of the Rhizopoda. Resting on these facts F. E. Schulze has attempted to represent by the aid of a genealogical tree the mutual affinities and derivation from one another of the various members of the Rhizopoda. The base of the tree where its stem is as yet undivided, consists of the primitive forms--mere non-nucleated Cytodes represented by Haeckel's Monera (Protogenes, Protamaba, \&c.). From these by the differentiation of a nucleus in their protoplasm are evolved the nucleated forms (Ameba, fresh-water Monothalamia, Foraminifera, Heliozoa, \&c.) which constitute the sub-divisions into which the stem branches off. These repeat the various modifications of psendopodia (Lobose, Filiform, \&c.) which had already existed in the primitive forms, and which they thus derive by inheritance from their non-nucleated progenitors. Finally through the branch of the Heliozoa we are conducted to the ultimate twigs former by the families of the Radiolaria, in which we find not only nuclei but a "central capsule" indicating the highest grade of differentiation attained by any member of the group.

\section{THE NORWEGIAN DEEP-SEA EXPEDITION}

THE Norwegian Deep-Sea Expedition will bave started from Bergen on its second summer cruise in the steamer Boringen. It has been decided by the proper authorities that the expedition, like last year's, shall be commanded by Capt. Wille with Lieut. Petersen as first officer. The scientific staff of the expedition is also the same as the previous year with the exception of the chemist, whose post is this year filled by Herr H. Tornœ.

The following is the approved plan of the expedition of the present year.

The equipment of the vessel and the determination of its magnetic constants were to be completed by June I. In studying the temperature in the deep sea over the banks off the West Coast, it has become evident that accurate observations are wanting in the Norwegian Rende. In order to obtain these the vessel will go from Bergen direct to sea, and following the botton of the Rende, take accurate observations there. Farther to the north several of last year's observations may also be verified.

The first proper field of work is the Norwegian coast banks to the north of Ramdalen, From existing observations it is probable that the "Havbro," where the bank sinks toward the depths of the Polar Sea, and where the ice-cold water begins at the bottom, lies at least twenty-five geographical miles from the coast. Between Rœest and the point off Ramdalen, where the expedition last year found a depth of about sixty fathoms with a rocky bottom ten miles from land, it is considered probable that there runs a more or less continuous ridge of rock.

The position and characteristics of the "Havbro" and the supposed ridge form main points in the examination of the banks. This goes on by forming cross-sections perpendicular to the coast. The sections, like last year's, are to be at a distance of twelve or thirteen geographical miles asunder. Their inner boundary is to be the outermost line of the special hydrographical survey. Their outer boundary is where the temperature at the bottom of the sea is $\div \mathrm{I}^{\circ} \mathrm{C}$, , or thereby. In each"section besides the observation of the temperature at each sounding, at "least three other series of observations are required, one at the inner boundary, one at the "Havbro," at its inner edge, and one at the outer limit of the section. The number of soundings will depent on the bottom being found more or less even as the work goes on.

In order to leave as much time as possible for work in the depths of the Polar Sea, and at Jan Mayen and the Greenland ice, there will be carried on, along with the survey of the banks, the examination of the Umbellularia region to a depth of $\mathbf{r}, 000$ fathoms in every third cross-section. If circumstances permit 
several other bank-sections may also be extended to this depth: While working in this region it will be proper to call at Bodoe.

A series of observations of temperature made in West Fiord with the newest deep-water thermometers will be carried out both during the voyage northwards in June and during the return voyage in August, in order to examine the abnormal state of things found there in the summer of 1875 , the minimum temperature being at a depth of seventy fathoms. As the zoological surveys in West Fiord have hitherto only embraced the fauna of the coast, the opportunity will be sought to be utilised for zoological work in this fiord at a greater distance from land.

Magnetic absolute observations will be carried out at Røest, where circumstances, from Lieut. Petersen's observations in I 875, appear favourable, and where the most projecting point is found for comparison with the proposed observations on the Greenland ice.

In the course of June it is supposed, with average weather, and with the experience gained last year, that the survey of the banks and of the Umbellularia Region according to this plan will have reached the latitude of Tromsœ.

The expedition will in the end of June or beginning of July, be equipped for a cruise to the westward, going first along the line Andœ, Jan Mayen, surveying it and its neighbourhood on both sides. Round the north-east end of Jan Mayen as a centre, several series of soundings are to be taken towards the north-east, the north, and the north-west. For in that neighbourhood where the ontermost mountain of the Iceland volcanic region is supposed to be, the bottom appears to sink very rapidly towards the deep sea in the directions named.

Provided Jan Mayen can be reached, it is proposed to land on it for the purpose of undertaking an examination of its georraphy, geology, hydrography, zoslogy, botany, \&c. It is also intended to make a survey of the sea on the west and south sides of Jan Mayen, for there is ground for supposing that Jan Mayen is connected with Iceland by a sub-oceanic ridge.

In order to examine the phenomena at the bouridary between the warm surface current from the Atlantic and the coid polar current in the Greenland sea, the Greenland ice north-west of Jan Mayen will be visited. When the examination of a part of the Greenland ice is completed the course will be taken to a point about midway between Iceland and Jan Mayen, and the crosssection is to be examined from this point in the direction of Ranen with the view of discovering and exploring the supposed sub-oceanic ridge. When this cross-section is worked out to the Norwegian Umbellularia region, previously examined, the expedition will sail to Tromsoe to carry on work to the northward, if time permit.

As July is supposed to be devoted to the Jan Mayen cruise, the first half of August will be employed in a survey of the banks, the "Havbro" and part of the Polar Sea between Nor way and South Spitzbergen. The eastern limit will be the line North Cape, Bear Island, South Cape. The latter half of August will be devoted to the return voyage to Bergen and dismantling. The scientific work will be carried out mainly in the same way as in 1876 . In the zoological work, along with the use of the dredge, the trawl, and the swab, special weight is laid on the use of nets in the intermediate depths and fishing on the banks. On Jan Mayen the capture of birds ought to be an object of importance, and on the Greenland ice possibly seal and bear-hunting, \&c.

In taking soundings the form and extent of the banks is to be determined, and the way in which the bottom falls off from these 'to the greatest depths of the polar sea. It is of fundamental importance for understanding the orography and geology of this sea and the neighbouring land and for the distribution of animal life, whether the bottom falls off towards the deep sea with an even slope or in terraces and escarpments with plateaus lying between. The position and number of the soundings is therefore to be determined with this view.

The measurements of the temperature in the deep sea are to be carried out to the extent necessary for a certain determination of the isotherms in the deep water of the cross-sections. It is also to be kept in view that the points in the cross-sections may be used for longitudinal sections. The newest deep-sea thermometers are to be used as frequently as possible, along with those employed last year.

At every sounding a specimen of water is to be taken from the bottom, and at chosen places at intermediate depths. The specific gravity of all specimens is to be ascertained. At every sounding, also, specimens iof the bottom are to be taken and preserved for future examination, which is also to be done with the material of the bottom brought up by the dredge and trawl.

The chemical work is to be carried on mainly as last year The specific gravity of the surface-water is to be determined once or twice a day, and oftener at places where the state of the curren's or other circumstances render it desirable. Observa tions of the currents in the sea are to be carried out where circumstances make it desirable, and the weather permits.

Magnetic observations are to be carried out on board at sea, special weight being laid on obtaining declination observations, Absolute determinations are to be carried out at Rœest, and on the Greenland ice, besides the determination of the ship's mag. netic constants at Huso, and elsewhere where possible.

A geological survey is to be made of Jan Mayen, if a landing there is possible, to the extent circumstances may permit. It would be of great interest to carry out astronomical determinations of geographical position, topographical and hydro. graphical surveys on Jan Mayen. A determination of geographical position at Roest, in connection with the magnetic observations, is also desirable, as the place is not connected with the trigonometrical net.

Botanical observations and collections are to be carrried out on Jan Mayen to the greatest possible extent.

The meteorological observations on board are to be carried out in all essential points as in 1876 .

II. MoHiv.

\section{NOTES}

AMONG those on whom honours were conferred on the occasion of Her Majesty's birthday, was Dr. J. D. Hooker, Presir dent of the Royal Society and Director of the Royal Gardens, Kew. Dr. Hooker has been made a K.C.S.I.

Trie twenty-sixth annual meeting of the American Association for the Advancement of Science commences at Nashville on August 29. Our own association meets at Plymouth this year on August 15, under the presidency of Frof. Allen Thomson, of Glasgow.

WE have received the programme of an Anthropological Exhibition to be held in connection with the Paxis Interrational Exhibition of 1878 , under the superirterdence of the Paris Anthropological Society. That Society has nominated a large Commission to organise the exhibition, with Prof. de Quatrefages as president. M. Krantz has placed at the disposal of the Society a spacious and fine position in the central pavilion of the Trocadero Palace. The Commission makes a warm appeal to all interested in the progress of the anthropological sciences, both in France and abroad. It wishes to prepare a complete in. ventory of the present state of these sciences. The following are the classes under which the exhibition will be arranged:- $x$. Crania and bones, mummies, and specimens relating to the com. parative anatomy of the human races ; 2 . Instruments, methods of education; 3. Prehistoric and ethrological collections; 4. Photographs, paintings and drawings, sculpture, and modelling; 5. Geographical maps and tables relating to ethnology, prehistoric archæology, linguistic, demography, medical geography, \&c. ; 6. Books, journals, brochures. In order to facilitate the work of collection and arrangement, the Commission has ap. pointed the following members to superintend the special depart ments named:-Dr. Broca, I, rue des Saints-Pères, for what concerns Anthropological Societies; Dr. de Ranse, 4, place St. Michel, Anthropological Instruction; Dr. Topinard, 97, rue Rennes, General Anthropology and Craniology ; M. Gabriel de Mortillet, Château de St. Germain-en-Laye (Seine-et-Oise), Prehistoric Archæology and Anthropology; M. Girard de Rialle, 64 , rue de Clichy, Ethnography of Europe; $M$. Abel Hovelacque, 35 , rue de I'Université, Linguistic Anthropology; Di. Dureau, 16, rue de la Tour-d'Auvergne, Bibliography; Dr. Bertillon, 20, rue Monsieur-le-Prince, Demography, or the Statistical Study of Population, and Medical Geography; $M$. Louis Leguay, 3, rue de la Sainte-Chapelle, for all concerning the general management and arrangements. Fach of the gentle- 